\title{
Aromatase Inhibitors and Endometrial Adenocarcinoma: The Role of Hormone Receptor Assessment
}

\author{
Laura Paleari ${ }^{1,2 *}$ and Andrea DeCensi ${ }^{1,3}$ \\ ${ }^{1}$ Division of Medical Oncology, EO Ospedali Galliera, Italy \\ ${ }^{2}$ ALiSa Public Health Agency, Liguria Region, Italy \\ ${ }^{3}$ Wolfson Institute of Preventive Medicine, Queen Mary University of London, United Kingdom
}

Submission: April 09, 2018; Published: May 16, 2018

"Corresponding author: Laura Paleari, Division of Medical Oncology, EO Ospedali Galliera, via Volta 6, 16128 Genoa, Italy, Tel: +39-0105634502; Fax: +39-01057481090; Email: laura.paleari@galliera.it

\begin{abstract}
Although adenocarcinoma of the endometrium (EC) is a hormone dependent neoplasm, no hormone therapy has ever been registered and there are no clear guidelines for the determination of steroid hormone receptors in the tumor tissue. Aromatase inhibitors (AIs) have been hypothesized as an opportunity for treatment. This article briefly reviews the current evidence for the role of AIs and the potential prognostic/ predictive role of hormone receptors in the treatment of EC.
\end{abstract}

Keywords: Estrogen receptor; Progesterone receptor; Endometrial cancer; Aromatase inhibitors

\section{Introduction}

Endometrial carcinoma (EC) is the most common gynecological malignancy in the US with over 50,000 women each year, with a mortality of about 8,500 patients/year [1]. Adenocarcinomas encompass more than $90 \%$ of uterine cancers of which about $80 \%$ are linked to an excess of estrogens related to obesity and insulin resistance [2] (type I), and the remaining $20 \%$ of unknown etiology (type II) [1]. The incidence of EC has recently been found to increase with increasing BMI [2]. Compared with women with a normal BMI, the RR of diseasespecific mortality for obese with a $\mathrm{BMI}=30-34.9 \mathrm{~kg} / \mathrm{m} 2$ is 2.53 , and for morbidly obese women with a BMI $>40 \mathrm{~kg} / \mathrm{m} 2$, the $\mathrm{RR}$ is 6.25 [2]. Furthermore, one of the main risk factors for endometrial adenocarcinoma is represented by the excess of exogenous and endogenous estrogens. It has been shown that the use of estrogens for 10 years increase of 10-times the risk to develop EC [3]. Moreover, prospective cohort studies have been shown as an increased serum estrogen levels double the risk of cancer incidence [4]. Aromatase, the enzyme that converts androgens to estrogens, is present in the ovaries, placenta, and many peripheral tissues. In postmenopausal women, the action of aromatase produces the majority of circulating estrogen [5]. Studies have shown that EC express higher levels of aromatase compared to normal endometrium, hypothesized to function through a paracrine mechanism [6]. Aromatase inhibitors (AIs) act to block the action of the enzyme, and have been show to suppress up to $95-98 \%$ of all circulating estrogens [7]. In agreement with what was previously reported for breast cancer (BC) patients, AIs may find a clinical use in EC treatment. The results of a study conducted by Chlebowski and colleagues suggested that the use of AIs to lower circulating estrogen levels in $\mathrm{BC}$ patients might reduce the risk of developing EC compared to tamoxifen [8]. In line with this observation, a recent metaanalysis by the Early Breast Cancer Trialists' Collaborative Group (EBCTCG) on AIs versus tamoxifen in responsive to hormone therapy $\mathrm{BC}$, showed a reduced EC incidence in the group treated with AIs (10-year incidence $0.4 \%$ vs $1.2 \%$; RR=0.33, 95\%CI; 0.21-0.51) [9]. Given the magnitude of the RR reduction, the difference between AIs and tamoxifen is only partially consistent with the increased risk associated with the use of tamoxifen by itself, and suggests how AIs could effectively reduce the risk of EC compared to not carrying out any treatment.

The MAP3 prevention study selected healthy postmenopausal women at high risk for BC with a Gail score $>1.66 \%$, or previous atypical hyperplasia or lobular carcinoma in situ at the biopsy, or with previous mastectomy for ductal carcinoma 
in situ (DCIS) [10]. Patients were randomly assigned to receive exemestane $25 \mathrm{mg} /$ day or placebo for 5 years with a median follow-up of 35 months [10]. The study showed a $65 \%$ relative risk reduction for invasive $\mathrm{BC}(\mathrm{RR}=0.35,95 \% \mathrm{CI}$;) and less gynecologic cancers in the exemestane group compared to the placebo ones [10]. More recently, the prevention study IBIS II, showed that the use of anastrozole in postmenopausal women selected for family history or previous mastectomy for DCIS positive to estrogenic receptors (ER), reduced significantly the risk of $\mathrm{BC}$ [11]. After a median follow-up of 5 years, the intervention arm showed a $\mathrm{HR}=0.47$ (95\% CI; 0.32-0.68) on the onset of BC and 3 cases of EC with anastrozole versus 5 with placebo [HR= $0.61(95 \% \mathrm{CI}$; 0.15-2.54)] [11]. Lindemann and colleagues in a phase II study evaluated the efficacy and safety of exemestane in patients with advanced, persistent or recurrent EC [12]. Data showed a 10\% objective response rate (ORR) and a 6-month progression failure in $35 \%$ of patients with hormone receptor-positive tumors with a good tolerability since most of the recorded adverse events (AE) were of grade 1-2 [12]. Slomovitz et al. conducted a phase II study on patients with progressive or recurrent EC to evaluate the efficacy of treatment with everolimus plus letrozole with a 16-week clinical benefit rate (CBR) of $40 \%$ and an ORR $=32 \%$ [13]. In 2016, Bogliolo and colleagues performed a systematic review to assess the effectiveness of AIs in the treatment of advanced CE [14]. The potential clinical benefit of AIs in the treatment of advanced and recurrent EC was underlined, highlighting the need to investigate their best use depending on biological characteristics of EC such as hormone receptors expression and functions [14].

\section{Role of Hormone Receptors}

The role and expression of estrogen and progesterone receptors (ER, PgR) in the EC have extensively been studied $[15,16]$. ER/PgR have been found positive in about $85-90 \%$ of the well-differentiated EC, in those moderately differentiated the ER/PgR were positive in approximately $70-85 \%$ of the tumour cells, whereas only $13 \%$ of poorly differentiated EC had detectable levels of ER/PgR [15]. Recent studies have shown the importance of these receptors as prognostic and predictive biomarkers, which may predict the response to anti-hormonal therapy in EC $[17,18]$. In a cohort of 686 primary EC and 171 metastatic lesions, PgR expression was significantly associated with patient survival $(\mathrm{P}<0.001)$ while $\mathrm{PgR}$ loss is related to disease progression $23 \%$ of the primary tumors and $76 \%$ of metastases) with increased proliferation for both ER positive and negative EC [17]. Lack of ER was found to be associated with epithelial-mesenchymal transition (EMT), a crucial step during tumor progression and malignant transformation, and reduced survival $(\mathrm{P}<0.001)$ [17]. The efficacy of the AI anastrozole has been assessed by the Gynecologic Oncology Group (GOG) indicating a partial response of $14.8 \%$ and an overall survival of 6 months in advanced disease [19]. The response occurred mainly in patients with PgR positive cancer [18] Similarly, in patients treated with letrozole for ER and PgR positive advanced disease the response rate was $9.4 \%$ with a 6.7 months median duration of stable disease [20].

\section{Conclusion}

To date, the standard management of EC are surgery (total hysterectomy and bilateral salpingo-oophorectomy) or chemotherapy and radiation. Estrogen is a hormone that contributes to the proliferation of the endometrium, which may lead to endometrial hyperplasia and subsequently, neoplasia. In postmenopausal women, the action of aromatase produces the majority of circulating estrogen. Given the action of aromatase as the primary source of estrogen in postmenopausal women, it has been hypothesized that its inhibition would be effective in the treatment of EC. Clinical studies conducted so far provide indirect evidence on the activity of AIs in preventing and treating EC but do not allow clarifying the benefit in terms of OS and PFS. In order to investigate the role played by AIs in EC it could be useful consider the involvement of hormone receptors. Evaluation of ER/PgR expression should be routinely performed in endometrial cancer to guide treatment decisions. This suggests that more investigations are indicated including an analysis of receptor isoforms to definitely establish the clinical effectiveness of receptor quantification in EC.

\section{Acknowledgment}

This work was supported the Italian Association for Cancer Research (AIRC), grant IG 2014, Rif. 15468

\section{References}

1. Lortet-Tiulent J, Ferlay J, Bray F, Jemal A (2018) International pattern and trends in endometrial cancer incidence, 1978-2013. J Natl Cancer Inst 110(4): 354-361.

2. Onstand MA, Schmandt RE, Lu KH (2016) Addressing the Role of Obesity in Endometrial Cancer Risk, Prevention, and Treatment. J Clin Oncol 34(35): 4225-4230.

3. Grady D, Gebretsadik T, Kerlikowske K, Ernster V, Petitti D, et al. (1995) Hormone replacement therapy and endometrial cancer risk: a metaanalysis. Obstet Gynecol 85(2): 304-313.

4. Potischman N, Hoover RN, Brinton LA, Siiteri P, Dorgan JF, et al. (1996) Case-control study of endogenous steroid hormones and endometrial cancer. J Natl Cancer Inst 88(16): 1127-1135.

5. Gao C, Wang Y, Tian W, Zhu Y, Xue F, et al. (2014) The therapeutic significance of aromatase inhibitors in endometrial carcinoma. Gynecol Oncol 134(1): 190-195.

6. Watanabe K, Sasano H, Harada N, Ozaki M, Niikura H, et al. (1995) Aromatase in human endometrial carcinoma and hyperplasia: Immunohisto chemical, in situ hybridization, and biochemical studies. Am J Pathol 146(2): 491-500.

7. Folkerd EJ, Dixon JM, Renshaw L, A'Hern RP, Dowsett M, et al. (2012) Suppression of plasma estrogen levels by letrozole and anastrozole is related to body mass index in patients with breast cancer. J Clin Oncol 30(24): 2977-2980.

8. Chlebowski RT, Schottinger JE, Shi J, Chung J, Haque R, et al. (2015) Aromatase inhibitors, tamoxifen, and endometrial cancer in breast cancer survivors. Cancer 121(13): 2147-2155.

9. Early Breast Cancer Trialists' Collaborative Group (EBCTCG) (2015) Aromatase inhibitors versus tamoxifen in early breast cancer: patient- 
level meta-analysis of the randomized trials. Lancet 386(10001): 1341-1352.

10. Goss PE, Ingle JN, Alés-Martínez JE, Cheung AM, Chlebowski RT, et al (2011) Exemestane for breast-cancer prevention in postmenopausal women. N Engl J Med 364(25): 2381-2391.

11. Cuzick J, Sestak I, Forbes JF, Dowsett M, Knox J, et al. (2014) Anastrozole for prevention of breast cancer in high-risk postmenopausal women (IBIS-II): an international, double-blind, randomised placebocontrolled trial. Lancet 383(9922): 1041-1048.

12. Lindemann K, Malander S, Christensen RD, Mirza MR, Kristensen GB, et al. (2014) Examestane in advanced or recurrent endometrial carcinoma: a prospective phase II study by the Nordic Society of Gynecologic Oncology (NSGO). BMC Cancer 14: 68.

13. Slomovitz BM, Jiang Y, Yates MS, Soliman PT, Johnston T, et al. (2015) Phase II study of everolimus and letrozole in patients with recurrent endometrial carcinoma. J Clin Oncol 33(8): 930-936.

14. Bogliolo, Gardella B, Dominoni M, Musacchi V, Cassani C, et al. (2016) Effectiveness of aromatase inhibitors in the treatment in the treatment of advanced endometrial adenocarcinoma. Arch Gynecol Obstet 293(4): 701-708.
15. Bender DBT, Leslie KK (2011) Hormones and Receptors in Endometrial Cancer. Proc Obstet Gynecol 2(1): 25.

16. Socolov D, Socolov R, Lupascu IA (2016) Immunohisto chemistry in endometrial hyperplasia and endometrial adenocarcinoma. Rev Med Chir Soc Med Nat Iasi 120(2): 355-362.

17. Tangen IL, Werner HM, Berg A (2014) Loss of progesterone receptor links to high proliferation and increases from primary to metastatic endometrial cancer lesions. Eur J Cancer 50(17): 3003-3010.

18. Wik E, Raeder MB, Krakstad C, Trovik J, Birkeland E, et al. (2013) Lack of estrogen receptor-alpha is associated with epithelial mesenchymal transition and PI3K alterations in endometrial carcinoma. Clin Cancer Res 19(5): 1094-105.

19. Rose PG, Brunetto VL, VanLe L, Bell J, Walker JL, et al. (2000) A phase II trial of anastrozole in advanced recurrent or persistent endometrial carcinoma: a Gynecologic Oncology Group Study. Gynecol Oncol 78(2): 212-216.

20. Ma BB, Oza A, Eisenhauer E, Stanimir G, Carey M, et al. (2004) The activity of letrozole in patients with advanced or recurrent endometrial cancer and correlation with biological markers-a study of the National Cancer Institute of Canada Clinical Trials Group. Int J Gynecol Cancer 14(4): 650-658.

\section{Your next submission with Juniper Publishers will reach you the below assets}

- Quality Editorial service

- Swift Peer Review

- Reprints availability

- E-prints Service

- Manuscript Podcast for convenient understanding

- Global attainment for your research

- Manuscript accessibility in different formats

( Pdf, E-pub, Full Text, Audio)

- Unceasing customer service

Track the below URL for one-step submission https://juniperpublishers.com/online-submission.php 